\title{
Feeding Fish Oil and Linseed Oil to Laying Hens to Increase the n-3 PUFA of Egg Yolk
}

\author{
G. KRALIK ${ }^{1}$, Z. ŠKRTIĆ ${ }^{1}$, P. SUCHÝ ${ }^{2}$, E. STRAKOVÁ ${ }^{2}$, Z. GAJČEVIĆ ${ }^{1}$ \\ ${ }^{1}$ Josip Juraj Strossmayer University of Osijek, Faculty of Agriculture, Osijek, Croatia \\ ${ }^{2}$ University of Veterinary and Pharmaceutical Sciences, Brno, Czech Republic \\ Received February 4, 2008 \\ Accepted June 11, 2008
}

\begin{abstract}
Kralik G., Z. Škrtić, P. Suchý, E. Straková, Z. Gajčević: Feeding Fish Oil and Linseed Oil to Laying Hens to Increase the n-3 PUFA of Egg Yolk. Acta Vet. Brno, 2008, 77: 561-568.

The research was carried out to assess the possibility of egg yolk enrichment with n-3 PUFA through supplementation of fish oil (FO) and linseed oil (LO) to layer diet. A total of 84 ISA Brown laying hens were divided into three groups. Each group consisted of seven cages with four hens per cage. Groups received diets differing in combinations of oils. The diet fed to group E1 contained $1.50 \% \mathrm{LO}$ and $3.5 \% \mathrm{FO}$, group E2 had diets with $2.5 \% \mathrm{LO}$ and $2.5 \% \mathrm{FO}$, and group E3 was fed diets with 3.5\% LO and 1.5\% FO. Contents of fatty acids in oils, diets and egg yolks were analyzed. The egg yolk content of $\alpha$-linolenic acid ( $\alpha$-LNA) and omega-3 polyunsaturated fatty acids (n-3 PUFA) in total fatty acids was increased $(P<0.001)$ due to the increased content of linseed oil in hen diet and it was the most favourable in group E3. In groups E1, E2 and E3, the $\alpha$-LNA content was $3.25 \%, 4.33 \%$ and $5.18 \%$, respectively, and the $n-3$ PUFA content was $6.80 \%$, $7.22 \%$ and $8.50 \%$, respectively. The content of eicosapentaenoic acid was higher $(P<0.05)$ in egg yolks of group E1 than that of groups E2 and E3. No significant differences $(P>0.05)$ were found among groups in the docosahexaenoic acid content. The omega-6/omega-3 PUFA ratio in groups E1, E2 and E3 was 2.96, 2.93 and 2.49, respectively. Increased concentration of linseed oil and reduced concentration of rapeseed oil in diets resulted in less SFA $(P<0.001)$ and more n-3 PUFA in egg yolks. It was determined that laying hens have the ability to synthesize EPA and DHA from $\alpha$-LNA if they receive enough $\alpha$-LNA through their diets.
\end{abstract}

$\alpha$-linolenic acid, eicosapentaenoic acid, docosahexaenoic acid, egg yolk lipid

Complying with recent nutritional trends, consumers require balanced and healthy food, thus paying more attention to modified quality of eggs. Due to their biological effects, eggs enriched with omega-3 polyunsaturated fatty acids (n-3 PUFA) can be classified as functional food. Dietary intake of n-3 PUFA decreases the risk of heart disease, inhibits the growth of prostate and breast cancer, delays the loss of immunological functions, and is required for healthy foetal brain and visual development (Lewis et al. 2000). The research is focused on n-3 PUFA, such as $\alpha$-linolenic acid ( $\alpha$-LNA), eicosapentaenoic acid (EPA) and docosahexaenoic acid (DHA). Conversion of $\alpha$-LNA into EPA and DHA in humans is only $5-10 \%$ (Schreiner et al. 2004), thus it is necessary to ensure its daily dietary intake. Layer strain has a non-significant effect on fatty acid composition of egg yolk (Ahn et al. 1995; Grobas et al. 2001; Scheideler et al. 1998) but hen age plays an important role in it (Nielsen 1998). Yannakopoulos et al. (2005) reported that the concentration of $\alpha$-LNA, EPA and DHA in egg yolk increased from the $22^{\text {nd }}$ to the $32^{\text {nd }}$ week of laying capacity. The authors determined that the LA/ $\alpha$-LNA ratio was also affected by hen age, being more favourable in older hens. N-3 PUFA-enriched eggs can be produced by modifying hen diet (Yannakopoulos et al. 2005; Sari et al. 2002; Boruta and Niemiec 2002). Simopoulos (2003) reported that eggs produced in natural environment of Peloponnesus (uncultivated plants) contained 20 times more n-3 PUFA than standard eggs. The ratio of n-6/n-3 PUFA in standard eggs was $20: 1$, while eggs produced in natural environment had the ratio of $1: 1$ (Simopoulos 2003). To increase n-3 PUFA in eggs, Jiang et al. (1991) and Sparks 
(2006) recommended dietary supplementation with linseed oil (as it contains significant amount of $\alpha$-LNA), and Husveth et al. (2003) and Sparks (2006) recommended fish oil (due to EPA and DHA). The above mentioned fatty acids contained in a diet were deposited in egg yolk lipids through the hen organism (Scheideler and Froning 1996; Ferrier et al. 1995; Lewis et al. 2000; Husveth et al. 2003).

The aim of our research was to investigate supplementation of layer diet with different amounts of linseed oil and fish oil and their effect on the n-3 PUFA content in egg yolk. Fish oil is rich in n-3 PUFA, especially EPA and DHA, and linseed oil contains only $\alpha$-LNA in greater amounts, which is the precursor of EPA and DHA. This study focused on determination of effects of different combinations of oils supplemented to layer diets and how they affect the synthesis and deposition of n-3 PUFA in egg yolks.

\section{Materials and Methods}

Animals and diets

The research was performed with 84 ISA Brown laying hens 50 weeks of age. Hens were assigned to three dietary treatments with seven replicates per treatment. Each replicate consisted of four hens housed in one cage. Layers were fed isonitrogenous $(16.80 \% \mathrm{CP})$ and isocaloric $(11.5 \% \mathrm{MJ} / \mathrm{kg})$ diets containing $5 \%$ of oil (Table 1$)$. Group E1 was given a diet supplemented with $1.5 \%$ of linseed oil (LO) and 3.5\% of fish oil (FO), group E2 was fed diets containing $2.5 \%$ of $\mathrm{LO}$ and $2.5 \%$ of FO, and group E3 had diets supplemented with $3.5 \%$ of LO and $1.5 \%$ of FO. Feed and water were provided ad libitum. During a four-week experiment, a lighting regime of $16 \mathrm{~h}$ light and $8 \mathrm{~h}$ darkness was used. Fatty acids were determined in oils, diets and egg yolk.

Table 1. Diet composition

\begin{tabular}{|l|c|c|c|}
\hline Ingredients & $\%$ & Calculated composition & $\%$ \\
\hline Corn & 47.70 & Crude protein & 16.30 \\
\hline Toasted soybean & 20.50 & Crude fat & 8.61 \\
\hline Soybean cake & 4.00 & Crude fiber & 4.97 \\
\hline Sunflower cake & 6.60 & Ash & 14.57 \\
\hline Dehydrated alfalfa & 3.00 & Lysine & 0.85 \\
\hline Limestone & 11.20 & Methionine & 0.40 \\
\hline Monocalcium phosphate & 1.55 & Tryptophane & 0.20 \\
\hline Oil $1^{1}$ & 5.00 & Arginine & 1.12 \\
\hline Salt & 0.30 & Ca & 4.39 \\
\hline Methionine & 0.15 & Total P & 0.65 \\
\hline Vitamin-mineral premix & Available P & 0.38 \\
\hline Total & 0.50 & ME, MJ $/ \mathrm{kg}$ & 11.48 \\
\hline
\end{tabular}

${ }^{1}$ Diets differed in the content of linseed oil (LO) and fish oil (FO): E1 group 1.5\% LO + 3.5\% FO, E2 group 2.5\% $\mathrm{LO}+2.5 \% \mathrm{FO}$ and $\mathrm{E} 3$ group $3.5 \% \mathrm{LO}+1.5 \% \mathrm{FO}$

${ }^{2}$ Premix $\left(1 \mathrm{~kg}\right.$ ) contained: vitamin A 2,200 IU, vitamin $\mathrm{D}_{3} 400 \mathrm{IU}$, vitamin $\mathrm{E}_{3} \mathrm{mg} / \mathrm{kg}$, vitamin $\mathrm{K}_{3} 400 \mathrm{mg} / \mathrm{kg}$, vitamin $B_{1} 400 \mathrm{mg} / \mathrm{kg}$, vitamin $B_{2} 800 \mathrm{mg} / \mathrm{kg}$, nicotinic acid $6 \mathrm{mg} / \mathrm{kg}$, calcium panthotenate $1.6 \mathrm{mg} / \mathrm{kg}$, vitamin B $700 \mathrm{mg} / \mathrm{kg}$, vitamin $B_{4} 4 \mathrm{mg} / \mathrm{kg}$, folic acid $150 \mathrm{mg} / \mathrm{kg}$, biotin $10 \mathrm{mg} / \mathrm{kg}$, choline chloride $80 \mathrm{mg} / \mathrm{kg}$, vitamin $\mathrm{C}^{6} 4 \mathrm{mg} / \mathrm{kg}$, methionine $40 \mathrm{mg} / \mathrm{kg}$, iodine $160 \mathrm{mg} / \mathrm{kg}$, manganese $13.6-18.4 \mathrm{mg} / \mathrm{kg}$, zinc $12 \mathrm{mg} / \mathrm{kg}$, cobalt $48 \mathrm{mg} /$ $\mathrm{kg}$, iron $5 \mathrm{mg} / \mathrm{kg}$, copper $500 \mathrm{mg} / \mathrm{kg}$, selenium $30 \mathrm{mg} / \mathrm{kg}$, $\beta$-apo ester carotene acid $200 \mathrm{mg} / \mathrm{kg}$, canthaxanthin 600 $\mathrm{mg} / \mathrm{kg}$, and a plant base up to $1 \mathrm{~kg}$

\section{Determination of fatty acid composition}

On the last day of experiment, seven eggs were collected randomly from each group to determine the fatty acid content in yolk lipids. Fatty acids in diets and egg yolks were determined according to the method of Csapó et al. (1986).

The amount of $0.35 \mathrm{~g}$ of dried egg yolk was weighed into a flask, $8 \mathrm{ml}$ of concentrated hydrochloric acid was added and it was boiled for $60 \mathrm{~min}$. After chilling, $7 \mathrm{ml}$ of ethanol was added, then $15 \mathrm{ml}$ of diethyl ether, followed by one-minute shaking. The next extraction was with $15 \mathrm{ml}$ of benzene (b.p. $<60{ }^{\circ} \mathrm{C}$ ). After phase separation, organic phase that contained about $150-200 \mathrm{mg}$ of fat was separated and evaporated under vacuum on a rotadest. Then $4 \mathrm{ml}$ of $0.5 \mathrm{M}$ sodium hydroxide in methanol was added, and boiled in a water bath for $5 \mathrm{~min}$. Then $4 \mathrm{ml}$ of $14 \%$ boron trifluoride in methanol was added and boiled for $3 \mathrm{~min}$, followed by addition of $4 \mathrm{ml}$ of $\mathrm{n}$-hexane. It was boiled for $1 \mathrm{~min}$ and then the organic phase was brought to the neck of the flask with saturated 
sodium chloride solution. When phases separated, samples were taken from the organic phase, dried using sodium sulphate, and used for the analysis. The fatty acid methyl esters (FAMEs) were separated on a $10 \times 0.25 \mathrm{~mm}$ wall coated open tubular (WCOT) column equipped with CP-SIL 88 (FAME) stationary phase. The quantitation of FAMESs was obtained with a flame ionization detector (FID) at $270{ }^{\circ} \mathrm{C}$. The temperature of the splitter injector was $270{ }^{\circ} \mathrm{C}$, the carrier gas was helium with a head pressure of $235 \mathrm{kPa}$. The oven temperature was programmed from $140{ }^{\circ} \mathrm{C}(10 \mathrm{~min})$ with $10^{\circ} \mathrm{C} / \mathrm{min}$ increase to $235^{\circ} \mathrm{C}(26 \mathrm{~min})$. The injected volume varied between 0.5 and $2 \mu \mathrm{l}$. The instrument used was the Chrompack CP 9000 gas chromatograph (Chrompack B.V., The Netherlands, Middleburg).

The following acids were determined: lauric $(12: 0)$, tridecanoic $(13: 0)$, myristic $(14: 0)$, pentadecanoic $(15: 0)$, palmitic $(16: 0)$, heptadecanoic $(17: 0)$, stearic $(18: 0)$, arachidic $(20: 0)$, behenic $(22: 0)$, tricosanoic $(23: 0)$, lignoceric $(24: 0)$, palmitoleic $(16: 1)$, heptadecenoic $(17: 1)$, elaidic $(18: 1 \mathrm{t})$, oleic $(18: 1 \mathrm{c})$, eicosenoic $(20: 1)$, erucic $(22: 1)$, nervonic $(24: 1)$, linoleic $(18: 2 \mathrm{n} 6), \gamma$-linolenic $(18: 3 \mathrm{n} 6)$, eicosadienoic $(20: 2 \mathrm{n} 6)$, eicosatrienoic $(20: 3 n 6)$, arachidonic $(20: 4 n 6)$, docosadienoic $(22: 2 n 6)$, $\alpha$-linolenic $(18: 3 n 3)$, eicosatrienoic $(20: 3 n 3)$, eicosapentaenoic $(22: 5 n 3)$, docosapentaenoic $(22: 5 n 3)$, and docosahexaenoic $(22: 6 n 3)$ acids. Individual acids in diets and yolk lipids are expressed as a percentage of total fatty acids. The sum of saturated fatty acids (SFA) is presented as $\mathrm{C} 12: 0+\mathrm{C} 13: 0+\mathrm{C} 14: 0+\mathrm{C} 15: 0+\mathrm{C} 16: 0+\mathrm{C} 17: 0+\mathrm{C} 18: 0+\mathrm{C} 20: 0$ $+\mathrm{C} 22: 0+\mathrm{C} 24: 0$. The sum of monounsaturated fatty acids (MUFA) is presented as $\mathrm{C} 16: 1+\mathrm{C} 17: 1+\mathrm{C} 18:$ $1 \mathrm{t}+\mathrm{C} 18: 1 \mathrm{c}+\mathrm{C} 20: 1+\mathrm{C} 22: 1+\mathrm{C} 24: 1$. The sum of $\mathrm{n}-6$ PUFA is presented as $\mathrm{C} 18: 2 \mathrm{n} 6+\mathrm{C} 18: 3 \mathrm{n} 6+\mathrm{C} 20$ $: 2 \mathrm{n} 6+\mathrm{C} 20: 3 \mathrm{n} 6+\mathrm{C} 20: 4 \mathrm{n} 6+\mathrm{C} 22: 2 \mathrm{n} 6$, and $\mathrm{n}-3$ PUFA is presented as C18:3n3 + C20:3n $3+\mathrm{C} 22: 5 \mathrm{n} 3+$ $\mathrm{C} 22: 5 \mathrm{n} 3+\mathrm{C} 22: 6 \mathrm{n} 3$.

\section{Statistical analysis}

The influence of different treatments (combinations of oils) was determined by one-way analysis of variance (one-way ANOVA). When the treatment had a significant $(P<0.05)$ effect on the fatty acid content, differences between the groups were tested by Fisher's LSD-test. Analyses were performed using Statistica v.7.1 software (StatSoft, Inc., 2005).

\section{Results and Discussion}

The contents of fatty acids (FA) in fish oil and linseed oil as well as in diets (\% of total FA) are presented in Table 2. The analysis showed that supplemented oils differed in the fatty acid profile. Fish oil contained $37.12 \%$ of SFA, $21.03 \%$ of MUFA, $16.32 \%$ of n-6 PUFA and $33.60 \%$ of n-3 PUFA, with EPA + DHA taking up $33.23 \%$ of total FA. Linseed oil contained $8.51 \%$ of SFA, $18 \%$ of MUFA, $16.32 \%$ of $n-6$ PUFA and $57.17 \%$ of $n-3$ PUFA, out of which $\alpha$-LNA took up $56.97 \%$ of total FA. Linseed oil did not contain EPA and DHA.

Fatty acid composition of the diets depended on the concentration of linseed and fish oils. Hens of group E1 were fed diets containing 40\% of n- 6 PUFA (\% of total FA), whereas groups E2 and E3 had diets with n-6 PUFA in the amount of $37.71 \%$ and $33.17 \%$, respectively. Moreover, the n-3 PUFA content increased from 15.4\% (group E1) to $18.51 \%$ (group E2) and $21.74 \%$ (group E3). The highest content of $\alpha$-LNA was determined in group E3 $(17.67 \%)$, followed by group E2 (14.29\%) and group E1 (10.36\%). When compared to groups E2 and E3, EPA and DHA were present in a greater amount in group E1 due to a higher concentration of fish oil in the diet. The ratios of n-6 PUFA/n-3 PUFA of groups E1, E2 and E3 were similar, being 2.59, 2.04 and 1.53, respectively. Concentrations of some dietary n-3 PUFA in our study are in accordance with results obtained by other authors that also supplemented linseed oil and fish oil to hen diets (Rizzi et al. 2003; Mirghelenj et al. 2004; Huyghebaert et al. 2007; Schreiner et al. 2004).

Table 3 presents the content of fatty acids in egg yolks (\% of total FA). Different combinations of fish and linseed oils in the diets had a significant effect on the fatty acid profile of egg yolk, especially on the content of SFA and n-3 PUFA. Linseed oil and fish oil supplemented to hen diets in different amounts had a significant effect $(P<0.01)$ on the content of myristic (C14:0), palmitic (C16:0), and behenic (C22:0) acids. Dietary increase of linseed oil and decrease of fish oil affected the lowering of particular fatty acids (except for stearic acid, C18:0) and total SFA in egg yolk lipids, which is desirable with respect to human health. Different combinations of fish and linseed oils in hen diets had no significant effect $(P>0.05)$ on the content of the most represented monounsaturated acid 
Table 2. Content of fatty acids (\% of total fatty acids) in fish oil (FO) and linseed oil (LO), and in diets with different amounts of the oils

\begin{tabular}{|c|c|c|c|c|c|c|}
\hline \multicolumn{2}{|c|}{ Fatty acid $^{1}$} & \multirow{2}{*}{$\begin{array}{c}\begin{array}{c}\text { Fish } \\
\text { oil }\end{array} \\
0.18\end{array}$} & \multirow{2}{*}{$\begin{array}{c}\begin{array}{c}\text { Linseed } \\
\text { oil }\end{array} \\
-\end{array}$} & \multirow{2}{*}{$\begin{array}{c}\mathrm{E} 1 \\
1.5 \% \mathrm{LO}+ \\
3.5 \% \mathrm{FO} \\
0.03\end{array}$} & \multirow{2}{*}{$\begin{array}{c}\mathrm{E} 2 \\
2.5 \% \mathrm{LO}+ \\
2.5 \% \mathrm{FO} \\
0.03\end{array}$} & \multirow{2}{*}{$\begin{array}{c}\text { E3 } \\
3.5 \% \mathrm{LO}+ \\
1.5 \% \mathrm{FO} \\
-\end{array}$} \\
\hline Lauric & $12: 0$ & & & & & \\
\hline Tridecanoic & $13: 0$ & 0.07 & - & - & - & - \\
\hline Myristic & $14: 0$ & 6.11 & 0.04 & 1.25 & 1.08 & 1.10 \\
\hline Pentadecanoic & $15: 0$ & 1.07 & 0.02 & 0.27 & 0.19 & 0.35 \\
\hline Palmitic & $16: 0$ & 21.45 & 5.10 & 14.33 & 13.57 & 13.16 \\
\hline Heptadecanoic & $17: 0$ & 1.16 & 0.06 & 0.28 & 0.25 & 0.27 \\
\hline Stearic & $18: 0$ & 5.88 & 3.04 & 3.71 & 3.87 & 4.08 \\
\hline Arachidic & $20: 0$ & 0.73 & 0.15 & 0.72 & 0.64 & - \\
\hline Behenic & $22: 0$ & 0.11 & 0.10 & 0.34 & 0.33 & 0.31 \\
\hline Tricosanoic & $23: 0$ & 0.23 & - & 0.05 & 0.05 & 0.09 \\
\hline Lignoceric & $24: 0$ & 0.13 & - & 0.18 & 0.18 & 0.08 \\
\hline \multicolumn{2}{|l|}{$\Sigma$ SFA } & 37.12 & 8.51 & 21.16 & 20.20 & 19.45 \\
\hline Palmitoleic & $16: 1$ & 5.09 & 0.05 & 0.91 & 0.81 & 0.85 \\
\hline Heptadecenoic & $17: 1$ & 0.36 & 0.03 & 0.41 & 0.34 & 0.13 \\
\hline Elaidic & $18: 1 \mathrm{t}$ & 0.23 & - & - & - & - \\
\hline Oleic & $18: 1 \mathrm{c}$ & 12.09 & 17.68 & 21.32 & 21.70 & 23.81 \\
\hline Eicosenoic & $20: 1$ & 1.81 & 0.23 & 0.56 & 0.52 & 0.72 \\
\hline Erucic & $22: 1$ & 0.34 & 0.01 & 0.08 & 0.08 & - \\
\hline Nervonic & $24: 1$ & 1.11 & - & 0.14 & 0.14 & 0.13 \\
\hline \multicolumn{2}{|l|}{$\Sigma$ MUFA } & 21.03 & 18.00 & 23.42 & 23.59 & 25.64 \\
\hline Linoleic & $18: 2 \mathrm{n} 6$ & 2.60 & 16.09 & 39.25 & 37.06 & 32.07 \\
\hline$\gamma$-linolenic & $18: 3 n 6$ & 0.34 & 0.18 & 0.12 & 0.12 & 0.16 \\
\hline Eicosadienoic & $20: 2 n 6$ & 2.33 & 0.05 & 0.11 & 0.10 & 0.39 \\
\hline Eicosatrienoic & $20: 3 n 6$ & 0.52 & - & 0.17 & 0.15 & 0.14 \\
\hline Arachidonic & $20: 4 n 6$ & 1.64 & - & 0.22 & 0.18 & 0.33 \\
\hline Docosadienoic & $22: 2 \mathrm{n} 6$ & 0.82 & - & 0.12 & 0.10 & 0.08 \\
\hline \multicolumn{2}{|l|}{$\Sigma$ n-6 PUFA } & 8.25 & 16.32 & 40.00 & 37.71 & 33.17 \\
\hline$\alpha$-linolenic & $18: 3 n 3$ & 1.87 & 56.97 & 10.36 & 14.29 & 17.67 \\
\hline Eicosatrienoic & $20: 3 n 3$ & - & 0.13 & 0.05 & 0.05 & - \\
\hline Eicosapentaenoic & $20: 5 n 3$ & 10.30 & - & 1.64 & 1.42 & 1.45 \\
\hline Docosapentaenoic & $22: 5 n 3$ & 1.51 & - & 0.18 & 0.11 & - \\
\hline Docosahexaenoic & $22: 6 n 3$ & 19.93 & - & 3.19 & 2.64 & 2.63 \\
\hline \multicolumn{2}{|l|}{$\mathrm{EPA}+\mathrm{DHA}$} & 30.23 & - & 4.83 & 4.06 & 4.07 \\
\hline \multicolumn{2}{|l|}{$\Sigma$ n-3 PUFA } & 33.60 & 57.10 & 15.42 & 18.51 & 21.74 \\
\hline \multicolumn{2}{|c|}{$\Sigma$ n-6 PUFA/ $\Sigma$ n-3 PUFA } & 0.25 & 0.28 & 2.59 & 2.04 & 1.53 \\
\hline
\end{tabular}

${ }^{1} \mathrm{SFA}=$ saturated fatty acids; MUFA = monounsaturated fatty acids; $\mathrm{n}-6 \mathrm{PUFA}=$ omega- 6 polyunsaturated fatty acids; $\mathrm{EPA}=$ eicosapentaenoic acid; $\mathrm{DHA}=$ docosahexaenoic acid; n-3 PUFA = omega-3 polyunsaturated fatty acids

(oleic acid, $\mathrm{C} 18$ : 1c) as well as on the content of total MUFA in egg yolk lipids. However, higher contents of heptadecanoic (C17:1) and nervonic (C24:1) acids were determined in yolk lipids of hens fed diets supplemented with more fish oil than linseed oil. Moreover, with dietary increasing of fish oil and reducing of linseed oil, the trend of a slight increase in the MUFA content in egg yolk lipids was noticed. Although there were no significant differences $(P>0.05)$ determined with respect to the profile and content of n-6 PUFA, the trend of slight increase was noticed in the content of n-6 PUFA in yolk lipids of eggs from 
Table 3. Content of fatty acids (\% of total fatty acids) in egg yolk of hens fed diets with different amounts of linseed oil (LO) and fish oil (FO)

\begin{tabular}{|c|c|c|c|c|c|}
\hline \multicolumn{2}{|c|}{ Fatty acid $^{1}$} & \multirow{2}{*}{$\begin{array}{c}\mathrm{E} 1 \\
1.5 \% \mathrm{LO}+ \\
3.5 \% \mathrm{FO} \\
0.39 \pm 0.03^{\mathrm{a}}\end{array}$} & \multirow{2}{*}{$\begin{array}{c}\mathrm{E} 2 \\
2.5 \% \mathrm{LO}+ \\
2.5 \% \mathrm{FO} \\
0.33 \pm 0.04^{\mathrm{b}}\end{array}$} & \multirow{2}{*}{$\begin{array}{c}\text { E3 } \\
3.5 \% \mathrm{LO}+ \\
1.5 \% \mathrm{FO} \\
0.31 \pm 0.01^{\mathrm{b}}\end{array}$} & \multirow{2}{*}{$\begin{array}{c}\begin{array}{c}P \\
\text { value }\end{array} \\
0.005 \\
\end{array}$} \\
\hline Myristic & $14: 0$ & & & & \\
\hline Pentadecanoic & $15: 0$ & $0.15 \pm 0.02$ & $0.12 \pm 0.02$ & $0.12 \pm 0.01$ & 0.055 \\
\hline Palmitic & 16:0 & $23.23 \pm 0.77^{\mathrm{a}}$ & $21.84 \pm 0.48^{\mathrm{b}}$ & $21.25 \pm 0.40^{\mathrm{b}}$ & $<0.001$ \\
\hline Heptadecanoic & $17: 0$ & $0.41 \pm 0.04$ & $0.37 \pm 0.04$ & $0.34 \pm 0.05$ & 0.075 \\
\hline Stearic & 18:0 & $8.24 \pm 0.29$ & $8.57 \pm 0.36$ & $8.23 \pm 0.20$ & 0.142 \\
\hline Behenic & $22: 0$ & $0.03 \pm 0.01^{\mathrm{a}}$ & $0.00 \pm 0.00^{\mathrm{b}}$ & $0.03 \pm 0.01^{\mathrm{a}}$ & $<0.001$ \\
\hline \multicolumn{2}{|l|}{$\Sigma$ SFA } & $32.45 \pm 0.55^{\mathrm{a}}$ & $31.23 \pm 0.58^{\mathrm{b}}$ & $30.28 \pm 0.38^{\mathrm{c}}$ & $<0.001$ \\
\hline Palmitoleic & $16: 1$ & $2.22 \pm 0.37$ & $2.02 \pm 0.27$ & $1.92 \pm 0.33$ & 0.351 \\
\hline Heptadecanoic & $17: 1$ & $0.33 \pm 0.03^{\mathrm{a}}$ & $0.29 \pm 0.02^{\mathrm{b}}$ & $0.28 \pm 0.01^{\mathrm{b}}$ & 0.008 \\
\hline Elaidic & $18: 1 \mathrm{t}$ & $0.34 \pm 0.10$ & $0.35 \pm 0.06$ & $0.23 \pm 0.08$ & 0.076 \\
\hline Oleic & $18: 1 \mathrm{c}$ & $37.51 \pm 0.85$ & $37.51 \pm 2.11$ & $37.17 \pm 1.66$ & 0.928 \\
\hline Eicosenoic & $20: 1$ & $0.22 \pm 0.02$ & $0.22 \pm 0.01$ & $0.21 \pm 0.01$ & 0.832 \\
\hline Nervonic & $24: 1$ & $0.04 \pm 0.01^{\mathrm{a}}$ & $0.01 \pm 0.01^{\mathrm{b}}$ & $0.02 \pm 0.01^{\mathrm{a}}$ & 0.006 \\
\hline \multicolumn{2}{|l|}{ इMUFA } & $40.66 \pm 0.99$ & $40.42 \pm 2.24$ & $39.84 \pm 1.97$ & 0.766 \\
\hline Linoleic & $18: 2 \mathrm{n} 6$ & $18.88 \pm 1.23$ & $19.84 \pm 2.32$ & $20.00 \pm 1.81$ & 0.597 \\
\hline$\gamma$-linolenic & $18: 3 \mathrm{n} 6$ & $0.10 \pm 0.01$ & $0.11 \pm 0.01$ & $0.10 \pm 0.02$ & 0.251 \\
\hline Eicosadienoic & $20: 2 \mathrm{n} 6$ & $0.14 \pm 0.02$ & $0.16 \pm 0.02$ & $0.16 \pm 0.03$ & 0.388 \\
\hline Eicosatrienoic & $20: 3 n 6$ & $0.17 \pm 0.02$ & $0.14 \pm 0.02$ & $0.16 \pm 0.02$ & 0.090 \\
\hline Arachidonic & $20: 4 n 6$ & $0.81 \pm 0.04$ & $0.88 \pm 0.10$ & $0.91 \pm 0.10$ & 0.219 \\
\hline \multicolumn{2}{|l|}{ इn-6 PUFA } & $20.10 \pm 1.21$ & $21.13 \pm 2.36$ & $21.33 \pm 1.94$ & 0.558 \\
\hline$\alpha$-linolenic & $18: 3 n 3$ & $3.25 \pm 0.53^{\mathrm{c}}$ & $4.33 \pm 0.53^{\mathrm{b}}$ & $5.18 \pm 0.47^{\mathrm{a}}$ & $<0.001$ \\
\hline Eicosatrienoic & $20: 3 n 3$ & $0.04 \pm 0.01^{\mathrm{b}}$ & $0.07 \pm 0.01^{\mathrm{a}}$ & $0.08 \pm 0.02^{\mathrm{a}}$ & 0.002 \\
\hline Eicosapentaenoic & $20: 5 n 3$ & $0.25 \pm 0.02^{\mathrm{a}}$ & $0.20 \pm 0.04^{b}$ & $0.18 \pm 0.01^{\mathrm{b}}$ & 0.004 \\
\hline Docosapentaenoic & $22: 5 n 3$ & $0.27 \pm 0.03$ & $0.27 \pm 0.16$ & $0.22 \pm 0.05$ & 0.669 \\
\hline Docosahexaenoic & $22: 6 n 3$ & $2.99 \pm 0.36$ & $2.35 \pm 0.27$ & $2.90 \pm 0.75$ & 0.135 \\
\hline \multicolumn{2}{|l|}{$\Sigma$ n-3 PUFA } & $6.80 \pm 0.54^{b}$ & $7.22 \pm 0.31^{\mathrm{b}}$ & $8.56 \pm 0.45^{\mathrm{a}}$ & $<0.001$ \\
\hline \multicolumn{2}{|c|}{ 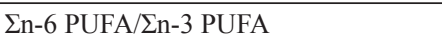 } & $2.96 \pm 0.23^{\mathrm{a}}$ & $2.93 \pm 0.29^{\mathrm{a}}$ & $2.49 \pm 0.25^{\mathrm{b}}$ & 0.026 \\
\hline \multicolumn{2}{|l|}{$\mathrm{EPA}+\mathrm{DHA}$} & $3.24 \pm 0.34$ & $2.55 \pm 0.28$ & $3.08 \pm 0.75$ & 0.117 \\
\hline
\end{tabular}

Data are means $\pm \mathrm{SD}$

a,b,c The values within the row differ significantly $(P<0.05)$

${ }^{1} \mathrm{SFA}=$ saturated fatty acids; MUFA = monounsaturated fatty acids; $n-6$ PUFA = omega- 6 polyunsaturated fatty acids; n-3 PUFA = omega-3 polyunsaturated fatty acids; EPA = eicosapentaenoic acid; DHA = docosahexaenoic acid

hens fed diets containing greater amounts of linseed oil. As it was expected, the increase in amounts of linseed oil over fish oil in hen diets resulted in increased content of $\alpha$-LNA (C18:3n3) in egg yolk lipids $(P<0.001)$. This is in accordance with the results of Lewis et al. (2000), and Husveth et al. (2003). The content of EPA (C20:5n-3) was higher (P $<0.05)$ in group E1 than in groups E2 and E3 due to a higher fish oil content in diets fed to E1 hens (3.5\%) than in diets fed to E2 and E3 hens $(2.5 \%$ and $1.5 \%$, respectively). The content of DHA (C22: 6n3) did not differ significantly among groups $(P>0.05)$. Hens' ability to convert $\alpha$-LNA into DHA probably influenced the deposition of DHA in egg yolk lipids of group E3. Huyghebaert et al. (2007) confirmed that diet composition influenced significantly the fatty acid profile in egg yolk, with the DHA fluctuation from 0.8 to $4.1 \%$. The DHA content in egg yolk was in a positive relation with the content of LNA and EPA+DHA in diets, and in a negative relation with the dietary content of linoleic acid 
(C18 : 2n6). The authors also pointed out that conversion of EPA into DHA was relatively limited due to the high concentration of DHA (Huyghebaert et al. 2007). Bavelaar and Beynen (2004) found out that egg yolk EPA can be modified through diets containing EPA, while egg yolk DHA can be modified by a diet rich in $\alpha$-LNA or by a diet containing DHA.

The increase of DHA in egg yolk as a result of dietary supplementation with fish oil was also found by Husveth et al. (2003) and Sari et al. (2002). According to these authors, the increase of n-3 PUFA in egg yolk lipids was accompanied by reduction of arachidonic acid concentration, which was not the case in our study. The total n-3 PUFA content in yolk lipids depended on the $\alpha$-LNA content $(P<0.05)$ and, following that presupposition, it was the highest in group E3 (3.5\% of linseed oil), followed by group E2 (2.5\% of linseed oil), while group E1 (1.5\% of linseed oil) had the lowest level of total n-3 PUFA. Scheideler and Froning (1996) also stated that supplementation of linseed oil and fish oil to hen diets resulted in a changed profile of fatty acids in modified eggs compared to standard eggs, and that change resulted in an increased content of desirable n-3 fatty acids. Rizzi et al. (2003) determined that the increase of n-3 FA in diets resulted in decreased n-6 FA in egg yolk, which was also previously confirmed by Herber and Van Elswyk (1996), and Meluzzi et al. (2000). In feeding hens, Mirghelenj et al. (2004) used linseed, rapeseed and fish flour (2.5, 5 and $5.5 \%$, respectively). The LNA content was high in the egg yolk of hens fed with linseed. By supplementing $7.5 \%$ of rapeseed to hen diets, yolk $\alpha$-LNA was increased three times, and by supplementation of linseed, it was even 17 times higher than that in the control. The n-6/n-3 PUFA ratio was the most favourable in diets supplemented with linseed (Mirghelenj et al. 2004).

The desirable ratio of n-6/n-3 PUFA less than $4: 1$ was determined in egg yolk lipids of all groups. This is in line with current nutritional trends (Lewis et al. 2000). However, group E3 had a better n-6/n-3 PUFA ratio $(P<0.05)$ than other groups. In the study of Sari et al. (2002), dietary supplementation with linseed $(0,5,10$ and $15 \%)$ increased the concentration of n-3 PUFA ( $\alpha$-LNA, EPA and DHA), which resulted in the reduction of the $\mathrm{n}-6 / \mathrm{n}-3$ PUFA ratio in egg yolk (13.12, 3.19, 2.36 and 1.88, respectively). This result was also confirmed by Ferrier et al. (1995), Scheideler and Froning (1996), and Beynen (2004).

Considering possibilities of enrichment of egg yolks with n-3 PUFA, our results showed that the combination of $3.5 \% \mathrm{LO}+1.5 \% \mathrm{FO}$ in the hen diet was more efficient than combinations of $1.5 \% \mathrm{LO}+3.5 \% \mathrm{FO}$ and $2.5 \% \mathrm{LO}+2.5 \% \mathrm{FO}$. The EPA+DHA content did not differ significantly $(P>0.05)$ among dietary groups. It is concluded that the increase in linseed oil and decrease in fish oil in layer diets resulted in a significant $(P<0.001)$ decrease in the SFA content and an increase in the n-3 PUFA content in egg yolk lipids. Furthermore, our research confirmed the laying hens' ability to synthesize EPA and DHA from $\alpha$-LNA during metabolic processes if $\alpha$-LNA is present in sufficient amount (Cherian and Sim 1991).

\section{Krmení rybím tukem a Iněným olejem za účelem zvýšení n-3 PUFA ve vaječném žloutku}

Tato studie hodnotila možnost obohacení vaječného žloutku přidáním rybího tuku (FO) a lněného oleje (LO) do diet nosnic. Celkem 84 nosnice ISA Brown byly rozděleny do tř́i rovnocenných skupin tvořených sedmi klecemi. Slepice byly ustájeny v klecích po čtyřech a krmeny směsmi, které obsahovaly, kromě jiných krmiv, různé kombinace olejů. Směs podávaná skupině E1 obsahovala $1.5 \%$ LO a $3.5 \%$ FO, skupina E2 dostávala diety s $2.5 \% \mathrm{LO}$ a $2.5 \% \mathrm{FO}$ a skupina $\mathrm{E} 3$ byla krmena dietami s $3.5 \% \mathrm{LO}$ a 1.5 $\%$ FO. Obsah kyseliny $\alpha$-linolenové ( $\alpha$-LNA) a n-3 PUFA ve vaječném žloutku se signifikantně zvýšil $(p<0.001)$ následkem zvýšeného obsahu lněného oleje v dietě slepic a 
byl nejpříznivější u skupiny E3. Obsah $\alpha$-LNA a n-3 PUFA byl u skupiny E1 $3.25 \%$ a $6.80 \%$, u skupiny E2 $4.33 \%$ a $7.22 \%$ a u skupiny E3 $5.18 \%$ a $8.50 \%$. Obsah kyseliny eikosapentaenové byl signifikantně vyšší $(p<0.05)$ ve vaječném žloutku skupiny E1 než skupin E2 a E3. Nebyly zjištěny signifikantní rozdíly $(p<0.05)$ mezi skupinami v obsahu kyseliny dekosahexaenové. Poměr n-6/n-3 PUFA byl u skupiny E1 2.96, u skupiny E2 2.93 a u skupiny E3 2.49.

\section{Acknowledgement}

This study was part of a research project financed by the Ministry of Science and Technology of the Republic of Croatia.

\section{References}

AHN DU, SUNWOO HH, WOLFE FH, SIM JS 1995: Effects of dietary alpha-linolenic acid and strain of hen on the fatty acid composition, storage stability, and flavor characteristics of chicken eggs. Poult Sci 74: $1540-1547$

BAVELAAR FJ, BEYNEN AC 2004: Relationships between the intake of n-3 polyunsaturated fatty acids by hens and the fatty acid composition of their eggs. Int J Poult Sci 3: 690-696

BEYNEN AC 2004: Fatty acid composition of eggs produced by hens fed diets containing groundnut, soya bean or linseed. NJAS-Wagen J Life Sci 52: 3-10

BORUTA A, NIEMIEC J 2002: The effect of storage of hen eggs enriched in PUFA on their quality and composition of fatty acids in yolks. In: $11^{\text {th }}$ European poultry conference, 6-10 September. Bremen, Germany

CHERIAN G, SIM JS 1991: Effect of feeding full fat flax and canola seeds to laying hens on the fatty acid composition of eggs, embryos, and newly hatched chicks. Poult Sci 70: 917-922

CSAPO J, SUGÁR L, HORN A, CSAPÓ JNE J 1986: Chemical composition of milk from red deer, roe and fallow deer kept in captivity. Acta Agron Hung 3-4: 359-372

FERRIER LK, CASTON LJ, LEESON S, SQUIRES J, WEAVER BJ, HOLUB BJ 1995: Alpha-linolenic acid- and docosahexaenoic acid-enriched eggs from hens fed flaxseed: influence on blood lipids and platelet phospholipid fatty acids in humans. Am J Clin Nutr 62: 81-86

GROBAS S, MÉNDEZ J, LÁZARO R, DE BLAS C, MATEO GG 2001: Influence of source and percentage of fat added to diet on performance and fatty acid composition of egg yolks of two strains of laying hens. Poult Sci 80: 1171-1179

HERBER SM, VAN ELSWYK ME 1996: Dietary marine algae promotes efficient deposition of n-3 fatty acids for the production of enriched shell eggs. Poult Sci 75: 1501-1507

HUSVETH F, ROZSA L, MAGYAR L, BALI G, PAPOCSI P 2003: N-3 fatty acid enrichment of table eggs by adding a fish oil preparation (Nordos Fat $($ ) to the diet of laying hens. Arch Geflugelkd 67: 198-203

HUYGHEBAERT G, RAES K, MAERTENS L, ARNOUTS S, DELEZIE E 2007: The interactive impact of dietary PUFA on the deposition of DHA in the egg yolk. In: Proceedings of the $16^{\text {th }}$ European symposium on poultry nutrition, 30 August. Strasbourg, France, pp. 681-684

JIANG Z, AHN DU, SIM JS 1991: Effect of feeding flax and two types of sunflower seeds on fatty acid composition of yolk lipid classes. Poult Sci 70: 2467-2475

LEWIS NM, SEBURG S, FLANAGAN NL 2000: Enriched eggs as a source of N-3 polyunsaturated fatty acids for humans. Poult Sci 79: 971-974

MELUZZI A, SIRRI F., MANFREDA G, TALLARICO N, FRANCHINI A 2000: Effects of dietary vitamin E on the quality of table eggs enriched with n-3 long-chain fatty acids. Poult Sci 79: 539-545

MIRGHELENJ A, RAHIMI SH, BARZGAR M 2004: Comparison of n-3 fatty acids sources for enrichment of egg. In: XXII worlds' poultry congress, 8-13 June. Istanbul, Turkey, pp. 8-13

NIELSEN H 1998: Hen age and fatty acid composition of egg yolk lipid. Brit Poult Sci 39: 53-56

RIZZI L, SIMIOLI M, BOCHICCHIO D, PARAZZA P 2003: The effects of omega-3 fatty acids, iodine and selenium supplementation of laying hen feed on the egg quality. In: Proceedings of the $\mathrm{X}^{\text {th }}$ European symposium on the quality of eggs and egg products, 23-26 September. Saint Brieuc, France, pp. 296-302

SARI M, AKŞIT H, OZDOĞAN M, BASMACIOGLUU H 2002: Effect of addition of flaxseed to diets of laying hens on some production characteristics, levels of yolk and serum cholesterol, and fatty acid composition of yolk. Arch Geflugelkd 66: 75-79

SCHEIDELER SE, FRONING GW 1996: The combined influence of dietary flaxseed variety, level, form, and storage conditions on egg production and composition among vitamin E-supplemented hens. Poult Sci 75: 1221-1226

SCHEIDELER SE, JARONI D, FRONING G 1998: Strain and age effects on egg composition from hens fed diets rich in n-3 fatty acids. Poult Sci 77: 192-196

SCHREINER M, HULAN HW, RAZZAZI-FAZELI E, BOHM J, IBEN C 2004: Feeding laying hens seal blubber oil: Effects on egg yolk incorporation, stereospecific distribution of omega-3 fatty acids, and sensory aspects. Poult Sci 83: 462-473 
SIMOPOULOS AP, CLELAND LG (Eds.): 2003: Omega-6/omega-3 essential fatty acid ratio: The scientific evidence. World Rev Nutr Diet 92: VII-XIII

SPARKS NHC 2006: The hen's egg - is its role in human nutrition changing? Worlds Poult Sci J 62:308-315

STATSOFT, Inc. 2005: STATISTICA (data analysis software system), version 7.1. www.statsoft.com

YANNAKOPOULOS AL, TSERVENI-GOUSI AS, YANNAKAKIS S, YAMOUSTARIS A 2005: Yolk fatty acid composition of $\mathrm{w}-3$ eggs during the laying period. In: Proceedings of $\mathrm{XI}^{\text {th }}$ European symposium on the quality of eggs and egg products, 23-26 May. Doorweth, the Netherlands, pp. 375-378 